\title{
The Psychology of Love in Islam and Implications for Education
}

\author{
Syaidatun Nazirah Abu Zahrin ${ }^{1}$ \\ Centre of Liberal Studies \\ Institut Islam Hadhari \\ Faculty of Education \\ Universiti Kebangsaan \\ Malaysia \\ Maznah Hj. Ibrahim \\ Farah Aida Fadzil \\ Centre of Liberal Studies \\ Universiti Kebangsaan \\ Malaysia
}

\begin{abstract}
The Psychology of Love were studied extensively and scientifically in the West. However, that is not the case in the Muslim world. Muslim scholars have been discussing and preaching about love, but love has not been researched extensively from the psychological perspective. This research is an attempt to demonstrate that Muslims could be motivated to learn a proper understanding of the Psychology of Love from an Islamic viewpoint. This study argues that proper understanding of the love for Allah has embedded within it the love for the Prophet Muhammad (PBUH) and the love for the Qur'an and Sunnah which leads to deep, creative, and critical thinking, subsequently to the love for knowledge. In this study, actions have been outlined to help inculcate the Psychology of Love from an Islamic perspective especially in the field of education, which should produce a dynamic effect among the young generation and humanity in general.
\end{abstract}

Keywords: Psychology of Love, Islamic perspective, motivating thinking, Quran, Sunnah.

\subsection{Psychology of Love Defined}

What is Love? Asking this question implies a search for clearly defining features of universal relevance. Theory and research on the psychology of love have often proceeded from the assumption that various 'basic' processes, such as biological, cognitive, and/or evolutionary processes, underlie this complex human experience. From this perspective, the social context in which these processes unfold is relevant but is not the central focus. An alternative view is that the psychology of love can be understood only by considering the social structure in which the patterns of personal relationships unfold. From this perspective, the social context is pivotal (Dion, K.K \& Dion, K. L, 298: 2006).

When K. L Dion and Dion (1988) first wrote about the relation between the social context and the nature of love in the book The Psychology of Love, relatively little research in social psychology has taken a cultural perspective on close relationships. Now the field of close relationships, along with many other areas of psychology, has seen considerable growth of interest in the impact of culture and culture-related factors on intrapersonal and interpersonal processes (Dion, K.K \& Dion K. L, 299: 2006).

Whether the understanding of love concerns the individual, social or universal context, the broad meaning of love is meaningless if the central and most fundamental source of love is not taken into consideration. From an Islamic perspective, Allah is the source of love, and loving Allah is embedded in the meaning of taqwa, which is defined as the feeling of "fear, hope, and love towards Allah SWT" (Syaidatun \& Maznah, 2009).

Therefore, the psychology of love in Islam is broad and not confined to the common understanding of purely romantic love. This study argues that proper understanding of the love for Allah has embedded within it the love for the Prophet Muhammad (PBUH) and the love for the Qur'an and Sunnah. Subsequently, this study posits that the love for thinking will be motivated because the life of the Prophet Muhammad (PBUH) exemplified this love through his deeds and words.

\footnotetext{
${ }^{1}$ Author Note

We have no conflicts of interest to disclose.

Correspondence concerning this article should be addressed to: Syaidatun Nazirah Abu Zahrin, Centre of Liberal Studies, Universiti Kebangsaan Malaysia, 43600 UKM Bangi, Selangor, Malaysia. Email: syaidatun@ukm.edu.my
} 
Table 1: Various Types and Forms of Love from Western and Islamic Perspectives

\begin{tabular}{ll}
\hline Western Perspective & Islamic Perspective \\
\hline Acquisitive love & Intellectual love \\
Adolescent love & Emotional love \\
Adult love & Physical love \\
Altruistic love & Social love \\
Passionate love & Spiritual love \\
Benevolent love & Sexual love \\
Romantic love & Brotherly love \\
Companionate love & Divine love \\
Conjugal love & Maternal love \\
Consummate love & Paternal love \\
Courtly love & Love for Allah \\
'Deficit' love & Love for Prophet \\
Desperate love & Love for Islam \\
Empty love & Love for the Quran \\
Fatuous love & Love for Sunnah \\
Homosexual love & Love for good and piety \\
Lesbian love & Love for Ummah \\
Immature love & Love for fellow brothers \\
Mutual love & Love for oneself \\
Non-love & Love for Allah's creations \\
One-sided love & Love for wisdom \\
Unrequited love & Love for thinking \\
Parental love & Love for reading \\
Partnering love & Love for writing \\
Sibling love & Love for learning \\
True love & Love for a role model \\
\hline
\end{tabular}

Similarly, this study postulates that the love for the Qur'an and Sunnah guides its readers by provoking their minds to think deeply, creatively, and critically, and consequently leads to the love for knowledge. Love for knowledge will lead to love for mankind and other forms of love that exist in man's life by the will of Allah (refer to Figure 1).

Figure 1: Understanding the basis for the psychology of love through an Islamic perspective

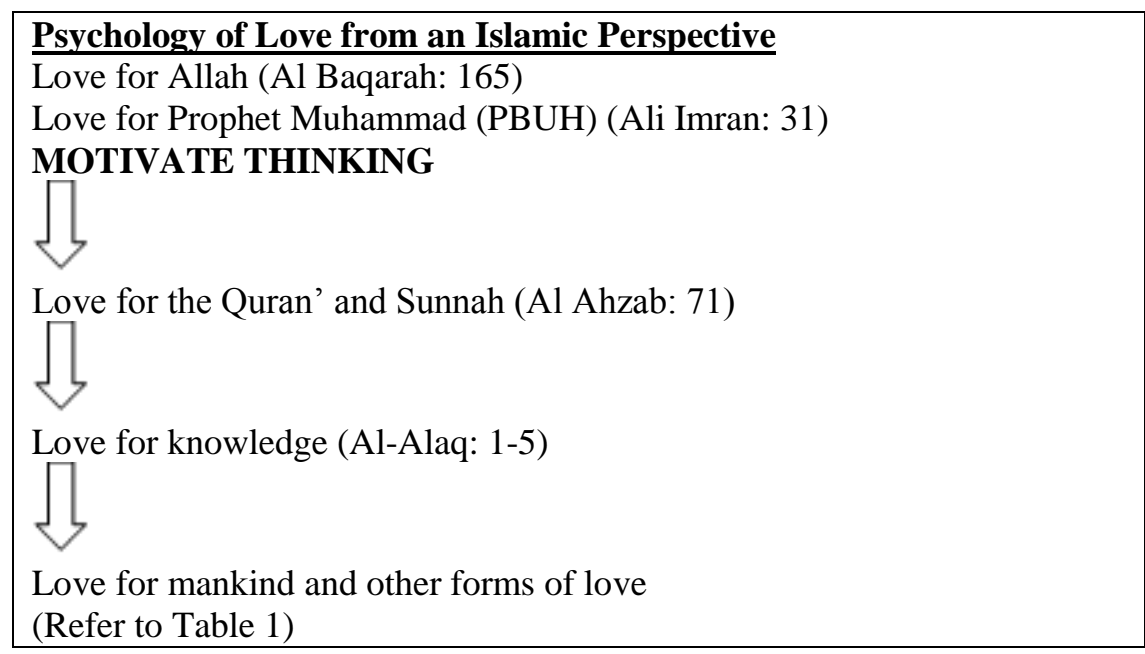

As a result of this study, a few proposals have been suggested to help inculcate the Psychology of love from an Islamic perspective especially in the field of education. This effort should produce a dynamic effect among the young generation and humanity in general. Psychologists, parents, teachers, educationalists, policymakers in the government, and the students themselves have a great role to play in understanding and actualizing the Psychology of love from an Islamic perspective as a motivating factor in thinking. 


\subsection{Background of the Study}

Allah, the Creator of mankind has provided men with the necessary apparatus for thinking and living a righteous life. HE has revealed the Qur'an as the true guidance $(h u d \bar{a})$, a shining light $(n \bar{u} r)$, and a cure (shif $\bar{a}$ ') for human problems. As true believers of the religion of Islam, which means total submission to Allah, Muslims should be leading their lives based on the Qur'an and the Sunnah of His Prophet and Messenger, Muhammad (PBUH). Muslims in the early days of Islam built a strong, creative, and brilliant Islamic civilization due to their love for Allah (God) and adhering to the teachings of Islam as revealed in the Qur'an and the Sunnah (Syaidatun 2004).

However today, the present Muslims are far less developed in most areas of life-social, economic, political, science, and technology and at the same time are too dependent on the West. They are more capable to be users rather become great inventors and creators like the Muslims of the early period. Not only that, Islam has been denigrated since September 11 and Muslims have been labeled as 'terrorists' and 'extremists'. The truth is; the backwardness and over-portrayal behavior of many Muslims are due merely to their ways of thinking, and not because of the teachings of Islām. Dr. Ali Shari'ati in his book, What is to be done: The enlightened thinkers and an Islamic Renaissance (1986) explained,

Up till now the West has been teaching our intellectuals and intelligentsia about the world. It has been telling us about what civilization or culture is... The West has interpreted and depicted things for us the way it thought of them and wanted us to think of them. Even our own religion, history, literature, art, historical figures and humanistic values have been explained to us by the West...Our thinkers, our scientists, researchers and even writers who are working with Islamic subjects and with Persian poetry, all are consumers of the imported products of the Western cultural machinery, thereby turning researchers, in fact, into mere translators of Western works ( $p$. 62).

Sharia'ti (1986) reminded that Muslims prefer to be mere consumers instead of becoming producers, and thus are mere copycats of Western works. In facing this challenge, Muslims should realize what they possess has the potential to maximize their thinking capacity and capability. They should be able to think ahead the time and not be complacent with their present state. The Qur'an always reminds Muslims to use their thinking faculty, as asserted by Lang (1997, p.26),

The Qur'an contains signs for those who are "wise" (2:269), "knowledgeable" (29:42-43), "endowed with insight" (39:9), and "reflective" (45:13). Its persistent complaint against its rejecters is that they refuse to make use of their intellectual faculties and that they close their minds to learning. The Qur'anasks almost incredulously: "Do they not travel through the land, so that their hearts may thus learn wisdom?" (22:44), "Do they not examine the earth?" (26:7), "Do they not travel through the earth and see what was the end of those before them?" (30:9), "Do they not look at the sky above them?" (50:6), "Do they not look at the camels, how they are made?" (88:17), "Have you not watched the seeds which you sow?" (56:63).

An examination of early Islamic history reveals the religious piety and close adherence of early Muslim scholars to the Qur'an and the Sunnah. It was probably their love for God, the Qur'an and the Prophet that motivated their thought and resulted in their magnificent scientific, mathematical, and medical discoveries (Syaidatun, 2004).

Although thinking is cognitive, it is not separated from the affective domain. In most circumstances, thinking is triggered when the mind experiences an emotional disturbance such as being provoked by what is read, seen, heard, or felt. Emotions such as love motivate thinking. Realizing this, the study of the psychology of love and how it can motivate thinking from an Islamic perspective is then necessary so that Muslims can harness it fruitfully. This study is essential because the Islamic psychology of love and specifically the love for Allah are not clearly understood by Muslims themselves. The Psychology of love in the Islamic perspective is rarely explained in school, college or university, or even at home (Syaidatun \& Maznah, 2009).

Therefore, beginning from an early age, Muslims today should be motivated to think of the Psychology of love in such a way that they can once again generate a glorious age of learning out of love for knowledge. Muslims should sharpen their minds, contribute fresh ideas for change, express optimism, practice good thinking and possess a positive attitude to ensure that they are on the right track for progress, development, and prosperity both in this world and in the Hereafter, and thus making the love(s) they possessed as strong motivational factors in life. 
Appendix 1

\section{THE QUR'ANIC VERSES ON LOVE}

\begin{tabular}{|c|c|c|c|}
\hline No & $\begin{array}{l}\text { Surah(s): } \\
\text { Verse(s) }\end{array}$ & Translations & Content \\
\hline 1. & $\begin{array}{l}\text { Al- } \\
\text { Baqarah:165 }\end{array}$ & $\begin{array}{l}\text { Yet there are men who take (for worship) others besides Allah, } \\
\text { as equal (with Allah): They love them as they should love } \\
\text { Allah, but those of Faith are overflowing in their love for } \\
\text { Allah. If only the unrighteous can see. Behold, they would see } \\
\text { the punishment: that to Allah belongs all power, and Allah will } \\
\text { strongly enforce the Punishment. }\end{array}$ & $\begin{array}{l}2 \text { types of love: false } \\
\text { and true love }\end{array}$ \\
\hline 2. & $\begin{array}{l}\text { Al- } \\
\text { Baqarah:177 }\end{array}$ & $\begin{array}{l}\text { It is not righteous that ye turn your faces towards East or West: } \\
\text { but it is righteousness to believe in Allah and the Last Day, and } \\
\text { the Angels, and the Book, and the Messengers, to spend } \\
\text { yoursubstance, out of love for Him. }\end{array}$ & $\begin{array}{l}\text { Do righteous deeds } \\
\text { out of love for Allah }\end{array}$ \\
\hline 3. & $\begin{array}{l}\text { Al- } \\
\text { Baqarah:190 }\end{array}$ & $\begin{array}{l}\text { Fight in the cause of Allah those who fight you, but do not } \\
\text { transgress limits; for Allah loveth not transgressors }\end{array}$ & $\begin{array}{l}\text { Allah do not love } \\
\text { transgressors }\end{array}$ \\
\hline 4. & $\begin{array}{l}\text { Al- } \\
\text { Baqarah:195 }\end{array}$ & $\begin{array}{l}\text { And spend of your substance in the cause of Allah, and make } \\
\text { not your own hands contribute to (your) destruction; but do } \\
\text { good for Allah loveth those who do good. }\end{array}$ & $\begin{array}{l}\text { Allah loves does } \\
\text { who do good }\end{array}$ \\
\hline 5. & $\begin{array}{l}\text { Al- } \\
\text { Baqarah:205 }\end{array}$ & $\begin{array}{l}\text { When he turns his back, his aim everywhere is to spread } \\
\text { mischief through the earth and destroy crops and cattle. But } \\
\text { Allah loveth not mischief. }\end{array}$ & $\begin{array}{l}\text { Allah do not love } \\
\text { mischief }\end{array}$ \\
\hline 6. & $\begin{array}{l}\text { Al- } \\
\text { Baqarah:216 }\end{array}$ & $\begin{array}{l}\text { Fighting is prescribed upon you, and ye dislike it. But it is } \\
\text { possible that ye dislike a thing that is good for you, and that ye } \\
\text { love a thing that is bad for you. But Allah knoweth and ye } \\
\text { know not. }\end{array}$ & $\begin{array}{l}\text { One might love a } \\
\text { thing which is bad } \\
\text { for him }\end{array}$ \\
\hline 7. & $\begin{array}{l}\text { Al-Baqarah: } \\
276\end{array}$ & $\begin{array}{l}\text { Allah will deprive usury of all growth, but will give increase } \\
\text { for deeds of charity; For He loveth not creatures ungrateful and } \\
\text { wicked. }\end{array}$ & $\begin{array}{l}\text { Allah do not love } \\
\text { those who are } \\
\text { ungrateful and } \\
\text { wicked }\end{array}$ \\
\hline 8. & $\begin{array}{ll}\text { Al 'Imrān: } \\
14\end{array}$ & $\begin{array}{l}\text { Fair in the eyes of men is the love of things they covet: women } \\
\text { and sons; heaped-up hoards of gold and silver; horses branded } \\
\text { (for blood and excellence); and (wealth of) cattle and well- } \\
\text { tilled land. Such are the possessions of this world's life; but in } \\
\text { nearness to Allah is the best of the goals (to return to). }\end{array}$ & $\begin{array}{l}\text { They are love of } \\
\text { things in this world, } \\
\text { but the nearness to } \\
\text { Allah is the best goal }\end{array}$ \\
\hline
\end{tabular}

\subsection{Literature Review on Psychology of Love}

Human minds are flexible and open to new ideas and activities. One phenomenon that fascinates the youth is 'love'. They tend to have several interpretations of love, such as love for parents, for teachers, and friends, but the most highlighted is the love for the opposite gender, or what we call 'romantic love' (Sternberg \& Barnes 1988). Although Western scholars such as Abraham Maslow and Teresa of Avila, offer an understanding of love from the religious point of view (Sharon 1988), they do not cover all the five important domains of love; namely, intellectual, spiritual, emotional, physical, and social, as espoused by Muslim scholars. These scholars such as AlGhazālī, An-Nawāwī, Ibnu Qayyim Al-Jawziyyah, and Said Hawwā assert that there are many other meanings to the word 'love'. However, when the word 'love' is mentioned to the youth, it only conjures the image of a romantic relationship between male and female. The confusion and narrow understanding of the meaning of the psychology of love are not confined to the youth alone. It is also true for the Muslim society in general (Zahrin et al, 2017).

In a study on love, Nor Asiah (2001) alleges that Muslims lack a true understanding of love and are not emphasizing it much in the educational system. Another researcher, Md. Isa (2001) who studied affection and family bondage, claims that the free, liberal, peer relationship among today's teenagers is one of the major causes of social ills in our society. From the psychological perspective, Sternberg (1997) asserts that the lack of love towards learning and knowledge in the existing education system is among the major factors contributing to a decline in students' academic performance as well as their wellbeing inside and outside the school. Syaidatun (2013), on the other hand, discovered that there were many types of love and these love were based on the love for God and religion. 
A Muslim educationist, Prof. Ghulam Nabi Saqeb (1998) reminds Muslims of the need to internalize the true meaning of love in their educational system because, without this internalization, they will be locked in the psychology of fear that prevents them from becoming dynamic, proactive thinkers, educationists, and scholars.

To free themselves from the psychology of fear, Muslims should not let the disbelievers (the Non-Muslims) tell them how to think, but they should refer to the Qur'an and the Prophet Muhammad's traditions (Hadith) as their primary sources in making decisions in life. Relating to this matter, Allah says in the Qur'an "Verily, Allah will not change the state of a tribe, unless they themselves change their own state" (al-Qur'an, 13:11).

It has been argued (Nor Asiah, 2001) that the misunderstanding and confusion over "love" have resulted in many social problems in communities such as the disintegration of the family institution, rape, incest, drug addiction, murder, robbery, and disciplinary problems. The misunderstanding and narrow meaning of the word "love" has an impact on thinking and learning. When a man 'forgets' to use their minds in the best way possible and when thinking is neglected, the problems begin. Negligence in thinking is contradictory to the real nature of man as mentioned by Muhammad Abd. Ra'uf (1991), a prominent Muslim scholar,

It is true that man, like animals, is also driven by the force of his instincts with which man is endowed to ensure his physical survival. Yet, whereas the animal is driven by these inner natural forces alone (and it, therefore, answers their demands only instinctively and to extent of its needs) man, in view of his intellectual power, has the liberty and freedom to alter the time and the degree of his response to the forces of his sensual and selfish instincts. Therefore, man is in a state of a constant struggle between the forces of his excessive desires and the wisdom of his mind. His salvation lies in his ability to strike a balance between the pressures of his soul and the dictates of his consciences (p.xii).

Harūn Yahyā (2000: 6), a Muslim philosopher asserts, "Once a man begins to use this capacity, facts he has not been able to realize until that very moment begin to be uncovered by him. The deeper he goes into reflection, the more his capacity to think improves". For a person who always entertains hope under his faith in Allah, and who thinks positively, there is nothing that leads him to pessimism. The more a man reflects upon the Signs and Creation of God, the more he will realize the Mercy and Love of the Creator to mankind. This is where the psychology of love arises.

In her comparative study of the psychology of love, Nor Asiah (2000) found that Al-Ghazālī's model of love is more comprehensive than Maslow's model. She discovered that Al-Ghazālī's view of love encompasses a broader relationship towards the Creator, human beings, and all creations. She explained the "hierarchy of love" which encompasses love for Allah, Prophet Muhammad (PBUH), parents, Muslim brothers, and other creatures on the one hand. Maslow's types of love, on the other hand, are based on self, family, and social relations. She also indicated that the Islamic concept of love is rich in principles that are crucial in creating successful individuals who are accountable for all their deeds and well-being in this world, and the Hereafter.

Ghulam Saqeb Nabi (1998) traced how the psychology of love was originally embedded in Muslim education. He examines the ways in which Muslim education later lost this essential feature of love and surrendered to the colonial regimes that resulted in the malaise of the Ummah. The essential features of love mentioned by him were love as the fitrah of Allah, love breathed into the soul of man, Prophet Muhammad (PBUH) as the final restorer of the love of Allah, love as the foundation of the Islamic society of Madinah, and love embedded in Muslim Education. His writing highlights how past trends are gradually reversing and how Muslim education should be reconstructed for the future based on the Islamic psychology of love. According to him, the original qualities of love and the empathy upon which it was raised and for which it is spread worldwide, need to be researched, rediscovered, and re-introduced into the present-day Muslim education system to revive the true Islamic culture and revitalize the Ummah (Syaidatun, 2004).

Hence, the psychology of love should be taught and made clear to all Muslims, so that love will become an effective force in their life. Love can and should motivate positive thinking, which should be directed towards the betterment of the Ummah. Therefore, Muslims should be made aware of the proper understanding of the psychology of love so that it can be a remedy to problems related to education and critical thinking in general.

\subsection{Research Findings}

The most important part of this research is the implications of the psychology of love to the whole of mankind, particularly the education system. Before furthering this discussion, it is appropriate to ponder over a few questions before discussing the implications of the study for education. Do we teach our children in school to love Allah and the Prophet Muhammad (PBUH)? Do we teach our youth to love the Qur'an and the Sunnah to the extent that they attempt to apply, adopt, and manifest, with knowledge and awareness, the teachings in their everyday life? Do we teach our students to have a love for knowledge and a love for learning? If the answers to these questions are not yes, then these show that the educational system has missed an important ingredient for motivating sincere, fruitful, 
and beneficial thinking. This is possible if the educational objectives are secular or only emphasize the cognitive or intellectual domain while neglecting most of the emotional or affective and spiritual domains (Syaidatun, 2004).

Students, teachers, school administrators, lecturers, educators and parents must understand the psychology of love from an Islamic perspective as the main motivational factor for learning and thinking. Students must feel the presence of this love and the educators should motivate their students to love thinking and learning. This part of the discussion highlights the implications of this study for students, teachers and educators, parents, and the policymakers in the Education Ministry and Ministry of Higher Education. Some recommendations for the improvement of the educational system were also suggested.

\subsection{Psychology of Love: Implications for Education}

\section{Implications for Students}

One main implication of this study that should be significant to students, especially teenagers, is the clarification of the conception of the "Psychology of Love". This study has attempted to argue that the psychology of love in Islam is not confined to the typical romantic love with which the public has been exposed via mass media especially in dramas and movies. The psychology of love in Islam is vastly broader than that and has a significant purpose. Of all the types of 'love' discussed in the study, we have argued that the concept of 'love' for Allah is significant for Muslims for it acts as the 'water spring' from which other types of love flow (Syaidatun \& Maznah, 2009).

Secondly, we have demonstrated in this study how the love for Allah and Rasulullah (PBUH) motivates thinking. This finding is most significant for Muslim students. The ability to develop the love for Allah and Rasulullah (PBUH) in students will go a long way towards motivating them to think deeply. Once the students have developed this sincere feeling of love for Allah and His messenger, it is hoped that they will indulge themselves in pursuit of a life of learning and good deeds. The love for Allah requires as a prerequisite the love for the Qur'an. The Qur'an calls upon its reader to reflect, think, contemplate, and seek knowledge. Therefore, understanding the Qur'an is vital for Muslims if we want to cultivate the thinking of human beings. This could only happen if students were made to read and study the Holy Book daily, either in a programmed class lesson or at home. Consequently, the Qur'an should be an important basic text for all students (Please refer to Appendix 1 for the partial compilation of Qur'anic verses on love).

Thirdly, since knowledge of the Creator could also be derived from His signs that are manifested in the natural phenomena, students should be made to appreciate the various subjects that are taught in schools such as history, geography, and science. These subjects deal a lot with nature and proper teaching will also reveal the majesty, beneficence, wisdom, and mercy of the Creator besides understanding that all of HIS creations are to facilitate men in their lives. Thus, the heart of the students ought to feel this, leading them to love the Creator and subsequently, be spurred to further thinking and good, fruitful products.

\section{Implications for Teachers and Educators}

This study is significant and has various implications for teachers and educators concerning the subjects taught in class. As mentioned, the love for the Qur'an is a prerequisite for the love for Allah. Students' knowledge of the Qur'an and love for it can only be realized if they comprehend the Arabic language and Science of Qur'an. Therefore, Arabic language teachers should play a greater role in enhancing students' knowledge and command of the language. They must be familiar with various effective teaching methods. Also, they should integrate verses from the Qur'an in their teaching to familiarize their students with the Holy Book. In a sense, this will also make the learning of Arabic more meaningful and relevant to the students. Memorization of the Qur'an alone, without the understanding of its meanings, is inadequate to nurture the love for the Qur'an and consequently the love for Allah. The same goes for the love of Rasulullah (PBUH) and the love for Sunnah (Syaidatun, 2004).

Science teachers involved in the teaching of all kinds of natural and applied sciences should attempt to point out the Creator to their students. Many verses in the Qur'an refer to the natural laws or sunnatullah and these should be highlighted to students; for example, the constancy and precision of the movements of planetary bodies in the solar system (al-Qur'an, 36: 37-40). Muslim science teachers should be able to teach science and to relate it to the aesthetic and spiritual dimensions. Geography teachers, especially those involved in the teaching of physical geography should be able to teach students beyond the natural causes of the Earth's movement as reasons for the formation of volcanoes, lakes, etc. They should relate these phenomena as a manifestation of Allah's majesty and mercy to men as He asserts in the Qur'an (16:15), "And He has set upon the earth, mountains standing firm, lest it would shake with you, and rivers and highways that you may guide yourselves."

Muslim teachers and educators in the field of teaching thinking can benefit from this study by using the findings as to the content or as a reference for their teaching. By the virtue of love for Allah and the love for the Qur'an and the Sunnah, they will be able to provoke their students' thinking and invite them to think and to ponder upon the 
subject of love from different perspectives. Since the subject of love is crucial in one's life, it will be able to invite the students to share their opinions, ideas, and experiences which can create intellectual discussions in the class.

The teachers who can play the most significant role in developing the love for Allah and Rasulullah (PBUH) are teachers of Islamic Education; under the subject matter that they deal with, namely, faith, the Qur'an, and the Sunnah. Regrettably, the psychological testing movement has heavily influenced these teachers as well. Consequently, they too have begun to teach for the sake of passing examinations, which emphasize more on the cognitive domain, whereas religion is more importantly a matter of the heart. The spiritual domain has been side lined. Faith is taught more like a trade between rewards of paradise or torture of hellfire depending on one's deeds rather than the pleasure of pleasing God or the desire to see His Face. If this trend continues, it will be difficult for students to learn to acknowledge and love Allah. They might also become rigid in their belief without much love for others as well. Therefore, Islamic Education should refocus the object of their teaching to inculcating actions or deeds for the sake of loving Him and not just of fearing His hellfire. Actions because the former will have spiritual value while the latter will result in a hardened heart.

Prayer or fasting should not be taught mechanically as is the case today but must be prompted by the feeling of desiring to thank Allah for His Blessings, to praise Him for His Magnificence, and to repent for shortcomings. The quality of the prayer should be emphasized. Only then will students experience in prayer the sweetness of faith and love for Allah. In the teaching of the Qur'an, teachers ought to teach the skills of understanding, contemplating, and reflecting upon the Qur'an's deep meaning by applying the Arabic words they have learned. They should use approaches and techniques that make students think while learning Qur'an. The Qur'an has a lot of verses on human behavior, natural phenomena, history, and faith. Therefore, teachers should encourage their students to think over these matters in accordance with their ability and relate to the love for Allah SWT.

However, for the love for Allah and Rasulullah (PBUH) to develop in the students, it ought to be exemplified by teachers or adults. Hence, teachers should internalize the psychology of love on their personality (shakhsiah), actions ('amal), intentions (niyyat), and speeches (qaul) before they are able to impart them to their students.

\section{Implications for Parents}

Parents or family is another social agency that can also play a major role in the cultivation of the Islamic psychology of love in children. Parents should impress upon their children's minds the greatness, beneficence, mercy, and love of Allah. This can be explained through the ability to appreciate the beauty of nature, the flowers, the trees, the people, the mountains, the rivers, and the horizontal plains of green pastures which have been created by God for men and his other creatures. In order to convince their children of the existence of Allah, parents should motivate them to constantly ponder upon the creations of Allah, and simultaneously utter praises for Him. In the present world of music and melodies, certain lyrics of songs are arranged to contain praises for Allah and Rasulullah (PBUH). Parents can also inculcate the love for Allah and Rasulullah (PBUH) through these songs because rhyme is good for children and they love to sing them.

Parents can also narrate stories from the Qur'an and the history of the Prophets for lessons on faith and the triumph of truth over falsehood and good over evil. Stories of the Prophet Musa a.s. with the Pharoah, and other prophets such as Yūsuf, Ibrāhīm, Ismā'il, Sulaiman and others can also be related. These stories tell them of the power of Allah in assisting the prophets and destroying the unbelievers. There are simple storybooks available containing pictures with beautiful colors that will certainly attract children to look at and subsequently, read them. This approach will have a very positive impact on the minds of young children, and this will certainly help them to know and love Allah, His Prophets, and the Qur'an.

Parents should also make it a point to travel with their children to see the effects of those who were arrogant towards Allah, not only the beauty of His creations. This can create awareness in the children of the consequences of displeasing Allah and also His power to do whatever He desires to whomsoever He wishes. However, Allah has promised goodness for behavior as well.

The social ills that plague society today can be stamped out if children develop a love for Allah and, thus, obedience to His laws. They will prevent evil deeds. But love alone is not enough. They can still easily be tempted. Therefore, their thinking faculty should also be nurtured, that is their love for Allah should be extended to love for thinking as well. It was shown in a study by Khairul (2001) that children and adolescents with conduct disorder have poor intellectual functioning and show more depressive symptoms as well as lacking moral behavior judgment than normal children and adolescents. This means that those youngsters, even young adults, have not been able to use their minds to think well and this has led to deviant behaviors and social ills in society (Syaidatun et al 2015). Therefore, the youth needs to be able to think well and this study has shown one way to help them, which is through the Islamic psychology of love, via the love for the Qur'an and the Sunnah. 
This study, thus, recommends that Muslim parents teach their children the Islamic concept of 'love' beginning with the love for Allah, the Prophet, the Qur'an, and the Sunnah. Success in instilling the spirit of the love for Allah and Rasulullah (PBUH) in children will go a long way in helping them avoid all evils, wrongdoings, and social ills.

\section{Implications for the Ministry of Education and Ministry of Higher Education}

The Ministry of Education and Ministry of Higher Education needs to re-examine its illustration of the national education philosophy. The attainment of the goals of education concerning social, emotional, and spiritual aspects are overlooked. It is strongly felt that this dimension of 'psychology of love' is missing from our national school system. A review of the implementation of the educational philosophy would mean a re-examination of the school curriculum, teachers' training and the higher educational institutions.

This research would like to recommend the following points:

1. The teaching of the Arabic language should be made compulsory for all Muslim students up to a certain level. Knowledge of this language can help students to understand and comprehend the Qur'an and thus guide them to be righteous in their life as servants of God and as His vicegerents. Effective and innovative methods should be used, and specialist teachers ought to be trained for this purpose.

2. The curriculum of Islamic Education and its teaching approach should be revisited. There should be an emphasis on understanding over memorization of facts. Islamic Psychology of love and its subsequent ramifications should be placed very high on the goals of teaching this subject. The teaching of the five pillars of Islam and the six articles of faith should focus on the importance of the love for Allah, love for the Prophet's Sunnah, the Qur'an, good deeds and words, and the willingness to implement the Shariah.

3. Prayer or salāt is obligatory upon Muslims five times daily. Hence, special attention should be paid to the way it is taught. Allah promised in the Qur'an that prayer prevents shameful (fahisha') and evil deeds (mungkar), as mentioned: "Recite what is sent of the Book by inspiration to thee, and establish regular prayer: for prayer restrains from shameful and evil deeds..." (al-Qur'an, 29:45). Thus, if salät has achieved its objectives then social ills would not occur among the youth practicing it. Since social ills do occur, then the salät has not been effective.

It can be argued that this is possible because the salät taught in school is very mechanical - concerned only with the rules for its validity (rukun), its order (tartīb), and the invocations for it. Therefore, there should be more emphasize in the heart in prayer, to ensure it is involved in prayer and not just the physical presence.

4. In light of the above and effort to get students to love Allah, the teachers and educators should include a portion of Sufism (tasawwüf) with the objective to purify the heart. This is essential because before one can approach Allah, his heart has to be free from blemishes. This is possible through the practice of tasawwüf that encourages remembrance of Allah through dhikr. The heart has to be purified from all diseases such as hypocrisy (nifāq), the lower self (nafs lawwamah), and associating Allah with others (shirk). Diseases such as conceit (riya $\left.\bar{a}^{\prime}\right)$ and pride (takabbur) have to be removed too.

5. Teachers and educators who teach the Qur'an should take the opportunity to teach critical thinking from it. As mentioned previously, the Qur'an contains ideas on human personality and behaviors, social values, faith versus disbelief, natural phenomenon, history, and many others. Hence, reading its verses allows teachers to discuss with students their understanding of the verses and their significance in life.

6. The Ministry of Education and Ministry of Higher Education should also review its curriculum for Creative and Critical Thinking Skills (CCTS) offered to teacher trainees in teachers' colleges. Are the teachers being taught teaching for thinking or teaching about thinking? The emphasis should be on the former and not the latter. Since the study has argued the importance of the love for Allah as a factor that motivates thinking, then these teacher trainees ought to be taught this concept and its consequences. In other words, they should be taught that thinking is not only cognitive but also involves the affective domain. Muslim teacher trainees ought to be reacquainted with the Qur'an and the Sunnah in a new light - as a source for teaching thinking.

7. Finally, the Ministry of Education should be more critical in its teacher selection exercises. Only thinking teachers and educators can reproduce thinking students. Hence if it wants creative and critical thinking students, then these attributes must be an important consideration for all who aspire to teach in the school and the higher educational system.

\subsection{Summary and Conclusion}

In summary, this study has attempted to clarify and illustrate the psychology of love from the Islamic perspective and the role it plays in motivating thinking. To achieve its objective, the study first highlighted several issues and problems facing the Ummah and argued that one of the core roots of these is the non-existence of the culture of thinking among Muslims. 
In conclusion, we would like to reiterate what this study has demonstrated. It has shown that there is a significant relationship between the understanding of the psychology of love and thinking. One who truly understands this concept will be spurred to thinking more deeply. The concepts of love for the Qur'an and love for the Sunnah of the Prophet are two underlying ingredients to the psychology of love in Islam. This was the formula for the success of the early Muslims and Muslims today could regain that success through proper understanding of all these concepts. Motivating thinking through the understanding of the psychology of love from an Islamic perspective could be introduced in educational institutions. However, the curriculum and methods of instruction in various subjects, particularly the Islamic education, psychology and teaching thinking, should be re-examine to achieve this objective.

\section{References}

Ali, 'Abdullah Yūsuf. (1998). The Meaning of The Holy Qur'ān. $\left(9^{\text {th }}\right.$ ed). Maryland: Amana Publications.

al-Jauziyyah, Ibnu Qayyim. (1997). Cinta dan Rindu Menurut al-Qur'an dan as-Sunnah. (Translation of Raudhah al-muhibbin wanuzhah al-musytaqin). Trans. KathurSuhardi. Selangor: Al-Baz Publishing \& Distribution Sdn. Bhd.

al-Ghazali. (1982). Ihya Ulum-id-din, Vol. IV. Trans. Maulana Fazlul Karim. New Delhi: Kitab Bhavan.

al-Ghazali. (1998). Rindu dan Cinta Menurut Imam al-Ghazali [Longingness and love according to Imam al Ghazali]. Trans. Muhammad Aes Majid \& Hasan Ikhwani. Selangor: Pustaka Ilmi.

Abd. Ra'uf, Muhammad. (1991). The Muslim Mind Foundation and Early Manifestation. Kuala Lumpur: Dewan Bahasa dan Pustaka.

Dion L.D. \& Dion K. K. (1988). Romantic love: Individual and Cultural perspectives. In Sternberg Robert J \& Barnes Michael L (Eds),The Psychology of Love (pp. 264-289). Connecticut: Yale University Press.

Dion K.K. \& Dion L. D. (2006). Individualism, collectivism, and the Psychology of Love. In Sternberg, Robert J. \& Weis Karin. 2006. The New Psychology of Love.pp. 298-311. Connecticut: Yale University Press.

Hawwa, Sheikh Sa'id. (2001). Orang-Orang yang Dicintai Allah [People loved by Allah]. Malaysia: Perniagaan Jahabersa.

Harun Yahya. (2000). Deep Thinking. London: Ta-Ha Publishers Ltd.

Lang, J. (1997). Even Angels Ask. Maryland: Amana Publications.

Mahyuddin Haji Ashaari. (2001). Pendidikan al-Qur'an menjana keupayaan berjaya. Jurnal Pendidikan Islam,9(4), $1-8$.

Nor Asiah Jusoh. (2001). The psychology of love: Comparative study of al-Ghazali and Maslow. Unpublished directed research report. International Islamic University of Malaysia.

Saqeb, Ghulam Nabi. (1999). The psychology of love in Muslim education. Muslim Education Quarterly, 16(3), 3855.

Shari'ati, Ali. (1986). What Is to Be Done: The Enlightened Thinkers and an Islamic Renaissance. Houston: The Institute for Research and Islamic Studies.

Sharon, Brehm. (1988). Passionate Love. In Sternberg Robert J \& Barnes Michael L (Eds), The Psychology of Love(pp. 232-264). Connecticut: Yale University Press.

Sherman, R. R. \& Webb R. B. (1990). Qualitative Research in Education. London: The Falmer Press.

Sternberg, R.J. \& Barnes, M.L. (1988). The Psychology of Love. Connecticut: Yale University Press.

Sternberg, R.J. \& Barnes, M.L. (1997). Successful Intelligence. Kuala Lumpur: Syarikat First Agency Publishing (M) Sdn. Bhd.

Sternberg, Robert J. \& Weis Karin. (2006). The New Psychology of Love. Connecticut: Yale University Press.

Syaidatun Nazirah Abu Zahrin. (2004). Motivating Thinking Through the Concept of Love for Allah: Implications for Education. Education Master Thesis. International Islamic University of Malaysia.

Syaidatun Nazirah Abu Zahrin \& Maznah Ibrahim. (2009). The Psychology of Love in Islamic Perspective. International Seminar on Islamic Thought 2 (ISOIT2). Dewan Senat \& Dewan Majlis UKM. 6 \& 7 Oktober 2009.

Syaidatun Nazirah Abu Zahrin. (2013). Kefahaman remaja terhadap konsep cinta dalam Islam dan hubungannya dengan akhlak percintaan dan pemikiran rasional dalam percintaan. [The adolescents' understanding on the concept of love in Islam and its' relationship in the ethics of love and rational thinking]. Doctor of Philosophy Thesis. Universiti Kebangsaan Malaysia.

Syaidatun Nazirah Abu Zahrin, Fazilah Idris, Fariza Md. Sham, Rezki Perdani Sawai \& Joki Perdani Sawai. (2015). Psikologi agama dalam menangani gejala sosial remaja. Malaysian Journal of Youth Studies. Vol. 13, Dis. 2015, 187-203.

Zahrin, S. N. A., Idris, F., Mastor, K. A., Basir, A., Ismail, R., \& Osman, H. (2017). Relationship between Islamic Concept and Ethical Behavior (Akhlak) of being in Love among Youth (Hubungkait antara Konsep dan Tingkah Laku Etika (Akhlak) Percintaan menurut Islam dalam kalangan Belia). Akademika, 87(3). 